\title{
Control of fatty acid synthesis in lactation
}

\author{
By R. G. Vernon and D. J. Flint, The Hannah Research Institute, Ayr KA6 ${ }_{5} H L$, \\ Scotland
}

Lactation results not only in major changes in the metabolism of the mammary gland, but also in the metabolism of other organs of the body, for it is clear that the massive demands which lactation imposes on the body require a co-ordinated adaptation of metabolism in the whole animal (Bauman \& Currie, 1980; Williamson, 1980). Fatty acid synthesis provides a good example of such co-ordinated adaptation, for changes in lipogenic activity during lactation have been shown to occur in liver, white adipose tissue and brown adipose tissue as well as in the mammary gland. It is the nature and regulation of these adaptations which will form the main thesis of this review.

\section{Rates of fatty acid synthesis during lactation}

In most studies, changes in the rate of fatty acid synthesis with and during lactation have been measured in vitro using either tissue slices, isolated cells or, in the case of mammary gland, isolated acini and using saturating concentrations of substrates. Results from such preparations have to be treated with caution (Mayer, 1978) and are not necessarily the same as those occurring in vivo; nevertheless they have provided useful information which in the case of the rat (Williamson, I 980 ) and mouse (Romsos et al. 1978) have been confirmed (qualitatively) by measurement of the rate of fatty acid synthesis in vivo. Changes in the capacity for fatty acid synthesis can also be inferred from changes in the activity of key lipogenic enzymes, especially acetyl-CoA carboxylase which, as in liver and adipose tissue (Pearce, 1983 ), is thought to be rate limiting in the mammary gland (Bauman \& Davis, 1974, 1975; Smith \& Abraham, 1975; Williamson, 1980; McNeillie \& Zammit, 1982).

Mammary gland. Glucose and acetate are the main sources of carbon for fatty acid synthesis in mammary glands of rats and ruminants respectively (Bauman \& Davis, 1974, 1975; Patton \& Jensen, 1975; Dils, 1977; Mayer, 1978; Moore \& Christie, 1979); other species use intermediate amounts of both precursors (Dils, 1977); the species preferences for glucose and acetate are the same as in adipose tissue (Vernon, 1980). Ketone bodies also supply some $\mathrm{C}$ for fatty acid synthesis in ruminant (Bauman \& Davis, 1974; Patton \& Jensen, 1975; Moore \& Christie, 1979) and rat (Williamson, 1980) mammary glands. The extraction of acetate, glucose and ketone bodies in vivo by the mammary gland from a variety of species has been compared recently by Jones \& Parker (1978). Fatty acid synthesis from lactate has been demonstrated in rat (Katz et al. 1974; Yang \& Baldwin, 1975; 
Bartley \& Abraham, 1976) and bovine (Baldner et al. 1982) mammary tissue in vitro. There is a net uptake of lactate by rat (Williamson, 1980) and goat (Linzell, 1974) mammary gland indicating that lactate may contribute to fatty acid synthesis in vivo.

Glucose oxidation by the pentose phosphate pathway is thought to be the major source of NADPH for fatty acid synthesis in rat mammary gland, the remainder being derived from malate oxidation by malate dehydrogenase $\left(\mathrm{NADP}^{+}\right)$(Bauman \& Davis, 1974, 1975; Mayer, 1978). On the other hand, studies in vitro (Bauman \& Davis, 1974, 1975; Mayer, 1978; Moore \& Christie, 1979) and in vivo (Chaiyabutr et al. 1980) have shown that glucose oxidation via the pentose phosphate pathway can provide only $30-40 \%$ of the NADPH requirements in the mammary gland of ruminants; this contrasts with adipose tissue in which the pentose phosphate pathway is thought to be the main source of NADPH (Vernon, 1980). In both tissues (Bauman \& Davis, 1974, 1975; Mayer, 1978; Moore \& Christie, 1979; Vernon, 1980) oxidation of isocitrate by isocitrate dehydrogenase $\left(\mathrm{NADP}^{+}\right)$is thought to supply all of the additional NADPH required for fatty acid synthesis. Relative activities of isocitrate dehydrogenase $\left(\mathrm{NADP}^{+}\right)$and malate dehydrogenase $\left(\mathrm{NADP}^{+}\right)$of the mammary gland suggest that the former also has the more important role in NADPH production in the guinea-pig, rabbit and pig (Bauman \& Davis, 1974; Crabtree et al. 1981).

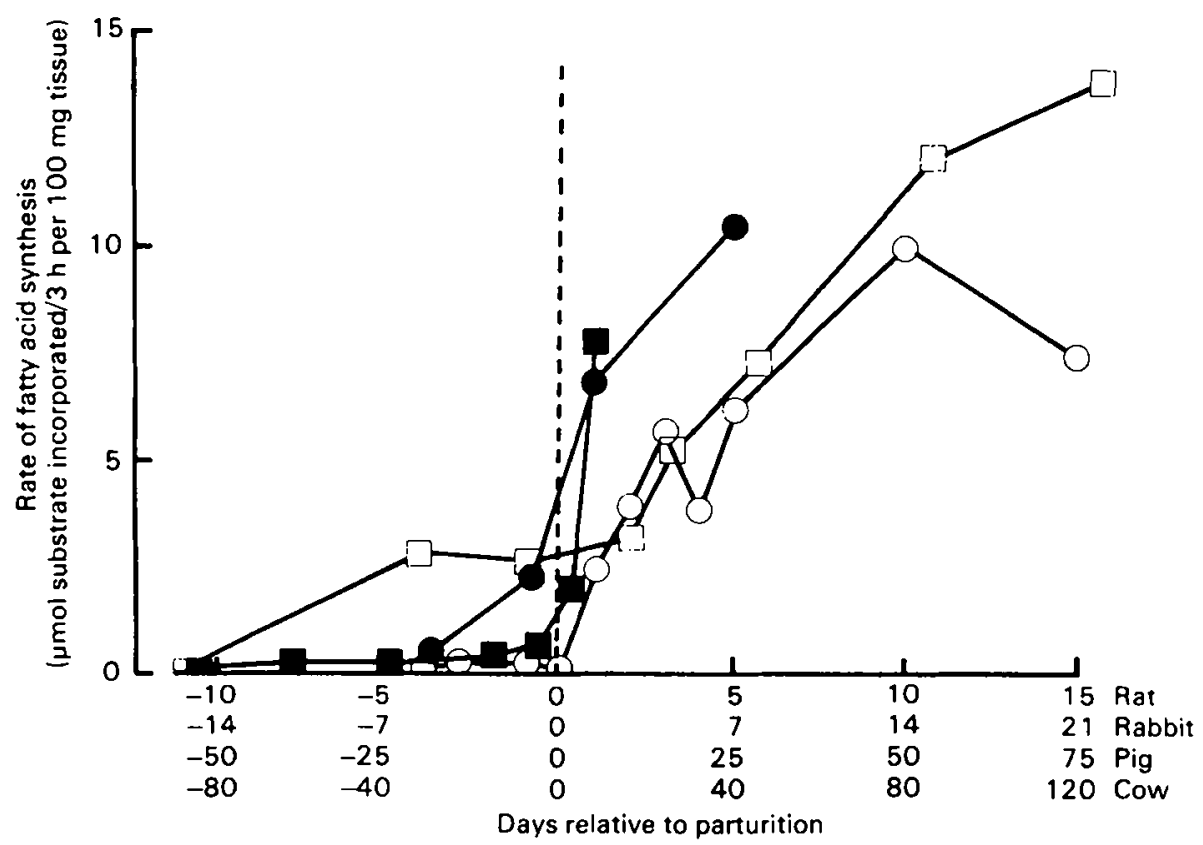

Fig. I. Rates of fatty acid synthesis in mammary tissue from rats $(O)$ (Martyn \& Hansen,1980), rabbits (D) (Mellenberger \& Bauman, 1974), pigs ( $\square$ ) (Kensinger et al. 1982) and cows (O) (Mellenberger et al. 1973) during late-pregnancy and lactation. The rate was measured using glucose (rats) or acetate in the presence of glucose (other species). 
Changes in the rate of fatty acid synthesis during late-pregnancy and lactation have been described for a variety of species including the rat, rabbit, pig and cow (Fig. I; Baldwin \& Yang, r974). In some species, including the pig and the cow, the rate of fatty acid synthesis begins to increase before parturition, whereas in the rat the increase commences post-partum (Fig. $\mathrm{I}$ ). The rabbit is unusual in that there is a surge in the rate of fatty acid synthesis early in gestation (Strong \& Dils, 1972) and a larger increase either just before (Strong \& Dils, 1972) or after (Mellenberger \& Bauman, 1974) parturition. The rate of fatty acid synthesis increases during early lactation and probably declines as milk yields fall.

Changes in the activities of almost all the major lipogenic enzymes have been described for many species (Baldwin \& Yang, I974; Bauman \& Davis, I974, I975; Dils, I 977; Mayer, 1978; Moore \& Christie, 1979). A notable exception is pyruvate dehydrogenase for which developmental changes have been described in the rat alone (Coore \& Field, I975; Kankel \& Reinauer, 1976). Total pyruvate dehydrogenase activity of the mammary gland is lower in ruminants than in non-ruminants (Read et al. 1977). Recently, activities of a number of lipogenic enzymes, including those involved in ketone body utilization, along with estimates of metabolic fluxes, have been reported for mammary glands from a variety of species (Crabtree et al. I98I).

Acetyl-CoA carboxylase is thought to have a critical role in regulating the conversion of acetyl-CoA to fatty acids in the mammary gland. A good correlation between total (i.e. post-citrate activation) acetyl-CoA carboxylase and the rate of fatty acid synthesis during late-pregnancy and lactation was found in the rabbit (Mellenberger \& Bauman, 1974) and cow (Mellenberger et al. 1973) mammary gland. Changes in the total acetyl-CoA carboxylase activity of the rat during lactation are due to changes in the amount of the enzyme (Mackall \& Lane, 1977). Hormonal induction of fatty acid synthesis in vitro in mammary explants from pregnant rabbits increases the synthesis of both acetyl-CoA carboxylase and fatty acid synthetase; in the case of fatty acid synthetase there is also a transient decrease in the rate of enzyme degradation (Mayer, 1978).

The increase in the rate of fatty acid synthesis with the onset of lactation is not due solely to an increase in the amounts of key enzymes, for in the rat, at least, the proportion of acetyl-CoA carboxylase (McNeillie \& Zammit, 1982) and pyruvate dehydrogenase (Coore \& Field, I975; Kankel \& Reinauer, 1976) in the active state are also increased. In addition, mammary acetyl-CoA carboxylase is subject to reversible phosphorylation and inactivation by both cyclic AMP-dependent (Hardie \& Guy, r 980) and cyclic AMP-independent protein kinase (McNeillie et al. I98I), but no changes in the phosphorylation state were apparent at different stages of lactation (McNeillie \& Zammit, I982).

Lactogenesis results not only in an increase in the rate of fatty acid synthesis in mammary tissue, but also in a change in the chain-length of the fatty acids produced. The usual product of fatty acid synthetase is palmitic acid but, during lactation, the mammary gland of most species produces high proportions of medium-chain fatty acids, while in some species (e.g. ruminants) it also produces 
short-chain fatty acids (Patton \& Jensen, 1975; Smith \& Abraham, 1975; Dils, 1977; Mayer, 1978; Moore \& Christie, 1979; Dils \& Knudsen, 1980; Smith, 1980): the varied mechanisms responsible have been reviewed recently (Dils \& Knudsen, r980; Smith, I980).

White adipose tissue: Lipid accumulation in adipose tissue during pregnancy followed by net mobilization during lactation has been demonstrated in non-ruminants (Spray, 1950) and ruminants (Vernon, 1980). Despite increased appetite, food intake is usually insufficient to meet the requirements of the animal during peak lactation, hence the need to mobilize fat.

The rate of fatty acid synthesis in white adipose tissue is decreased during lactation in mice (Romsos et al. 1978; Bartley et al. 1981), rats (Smith, 1973a; Farid et al. 1978; Robinson et al. 1978; Flint et al. 1979), sheep (Vernon et al. 1981) and cattle (Grichting, Baldwin et al. 1977; Grichting, Smith et al. 1977; Pike \& Roberts, 198I): in rats the fall begins approximately $2 \mathrm{~d}$ before parturition (Knopp et al. 1973; Smith, 1973a) and is complete by $2 \mathrm{~d}$ after parturition (Fig. 2 ). In cattle the rate increases between early and late lactation but by this time milk yields would have fallen and the animals would have moved from negative to positive energy balance (Grichting, Baldwin et al. 1977; Grichting, Smith et al. 1977).

The fall in the rate of fatty acid synthesis in rat adipose tissue around parturition was associated with a fall in the activities of several lipogenic enzymes including fatty acid synthetase and acetyl-CoA carboxylase (Farid et al. 1978; Sinnett-Smith et al. 1980). The amount of pyruvate dehydrogenase did not change

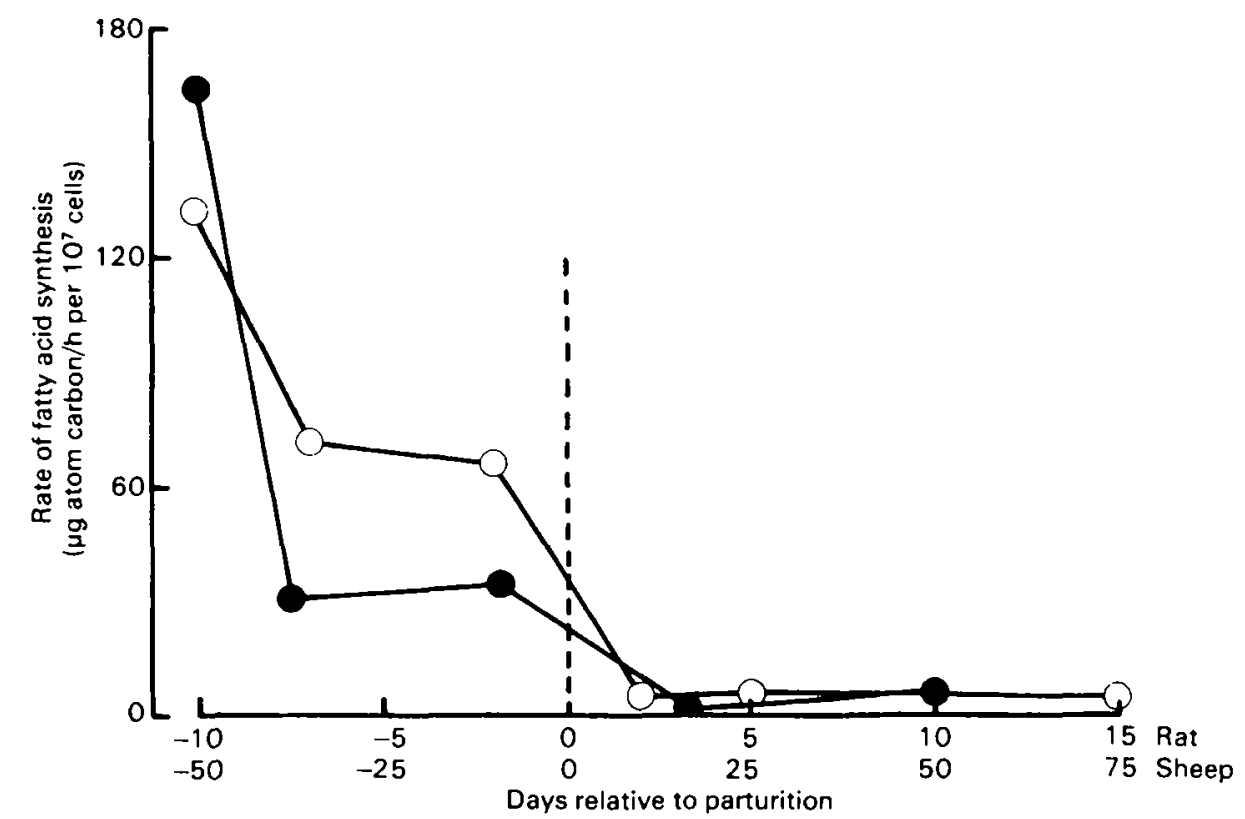

Fig. 2. Rates of fatty acid synthesis in adipocytes from rats $(O)$ (Flint et al. 1979 and unpublished observations) and sheep ( $($ ) (Vemon et al. I98I) during pregnancy and lactation. The rate was measured using glucose (rats) or acetate in the presence of glucose (sheep). 
but the proportion in the active state decreased (Sinnett-Smith et al. 1980). The fall in fatty acid synthetase activity was due to a decrease in the amount of the enzyme, resulting from a fall in the rate of enzyme synthesis and, probably, an increase in the rate of degradation (Sinnett-Smith et al. 1982). Acetyl-CoA carboxylase and malate dehydrogenase $\left(\mathrm{NADP}^{+}\right)$activities were lower in adipose tissue from lactating than from non-lactating goats (Chilliard et al. 1978).

The above changes are the reciprocal of those which occur in the mammary gland and suppression of fatty acid synthesis in adipose tissue means that it does not compete with the mammary gland for lipogenic precursors.

Brown adipose tissue. Brown adipose tissue has an important role in heat production in non-shivering thermogenesis and may also have a role in energy dissipation by so-called 'dietary-induced thermogenesis' (Rothwell \& Stock, 1 979); this latter capability appears to be decreased during lactation in rats (Trayhurn et al. 1982). The rate of fatty acid synthesis in brown adipose tissue of rats was markedly enhanced during pregnancy, but fell to low levels by mid-lactation (Fig. 3).

Liver. The liver is an important site of fatty acid synthesis in some species (e.g. rat, mouse, rabbit) but not others (e.g. ruminants, pig, guinea-pig) (Vernon, 1980). In the rat, hepatic fatty acid synthesis is raised during pregnancy, falls to normal

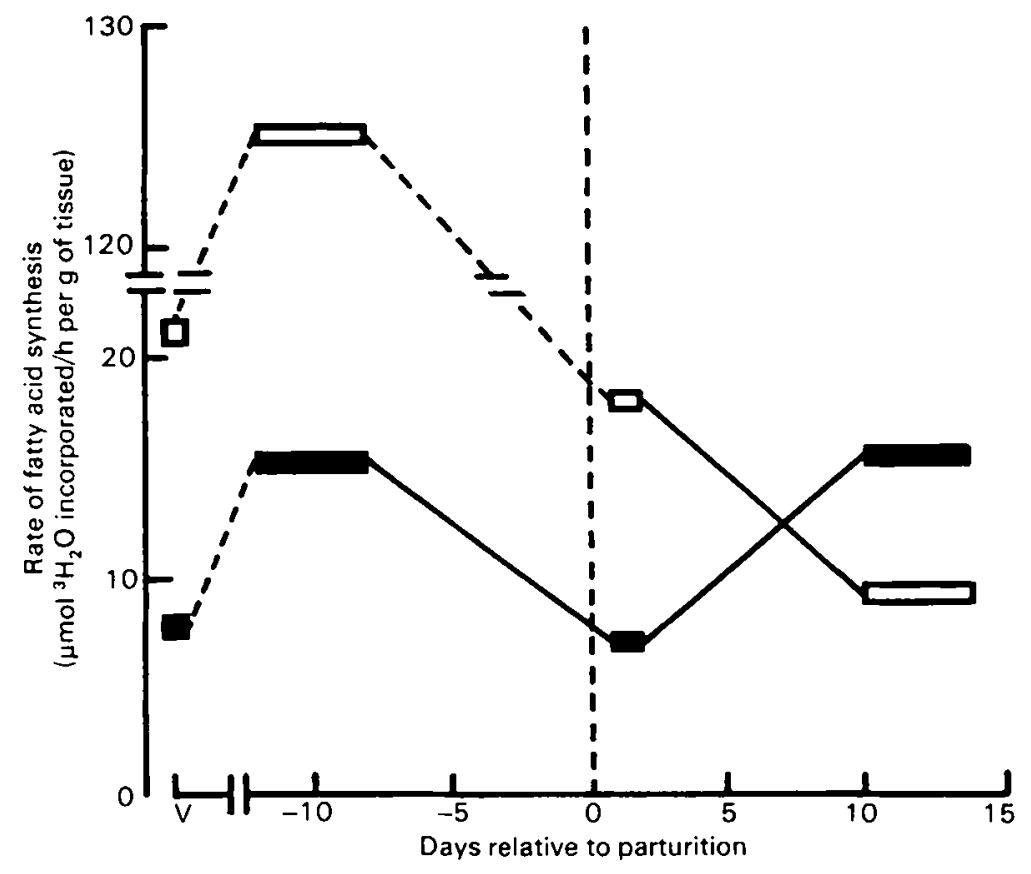

Fig. 3. Rates of fatty acid synthesis in liver ( $\square$ ) and brown adipose tissue ( $\square$ ) of rats during late-pregnancy and lactation (from Agius \& Williamson, 1980a). Rates were measured in vivo using ${ }^{3} \mathrm{H}_{2} \mathrm{O}$. V, virgin. 
levels by early lactation and is increased again by mid-lactation (Fig. 3) (Smith, $1973 b$; Agius \& Williamson, 1980a). These changes are paralleled by changes in the activity of acetyl-CoA carboxylase and several other lipogenic enzymes (Smith, I973b; Zammit \& Corstorphine, 1982). In contrast to the above, Farid et al. (1978) found no evidence for increased hepatic fatty acid synthesis during lactation in 4-6-month-old rats and a decreased rate during lactation in 8-10-month-old rats; effects of lactation may thus depend on age.

An increased rate of hepatic fatty acid synthesis was found in lactating mice (Romsos et al. 1978); changes in ruminants have not been reported, but the rate is normally very low in these species and would not be expected to rise during lactation in view of the increased rate of gluconeogenesis (Bell, 1979).

The physiological significance of increased hepatic fatty acid synthesis during lactation in rats and mice is not clear. The liver secretes triacylglycerols which can be used by the mammary gland, but the estimated rate of triacylglycerol secretion/g liver was lower in lactating than virgin rats and fatty acid synthesis contributed only $10 \%$ of the fatty acids secreted (Agius et al. 1981).

Relative contributions. The relative contributions of liver, white adipose tissue and mammary gland to total fatty acid synthesis have been reported for the mouse (Romsos et al. 1978; see Table I). Although the value for white adipose tissue is an underestimate as it includes dissectible deposits only, the results show that whereas liver and adipose tissue contribute about equally to total fatty acid synthesis in the virgin mouse, by mid-lactation the contribution of adipose tissue had fallen to less than $10 \%$ of that of the liver and the mammary gland accounted for approximately $75 \%$ of the total rate of fatty acid synthesis. Contributions of most other sites to total fatty acid synthesis, including brown adipose tissue, are small but some, such as the back, head and skin, make an appreciable contribution (Hollands \& Cawthorne, 1981). Agius \& Williamson (1980a) showed that in the rat, although the rate of fatty acid synthesis/g brown adipose tissue was relatively high, the total mass of brown adipose tissue was so small that the contribution to

Table I. Rates of fatty acid synthesis in vivo in liver, white adipose tissue and mammary gland of virgin and lactating mice*

$\begin{array}{lcc}\text { Liver } & \overbrace{\text { Virgin }}^{\text {Lactating (5 d) }} \\ \begin{array}{l}\text { Adipose tissue } \\ \text { (nmol }{ }^{3} \mathrm{H}_{2} \mathrm{O} \text { incorporated into } \\ \text { fatty acids/min per organ) }\end{array} \\ \begin{array}{l}\text { Mammary gland } \\ \text { Total }\end{array} & 74 \mathrm{I} & 2359 \\ 121 & 7059 \\ & 1846 & 954^{\circ}\end{array}$

•From Romsos et al. 1978. 
total fatty acid synthesis amounted to less than $5 \%$ and $0.6 \%$ of that of the liver in virgin and mid-lactating rats respectively.

Weaning. Removal of the young results in a rapid reduction in milk production and concomitant falls in the rate of fatty acid synthesis and activities of a variety of lipogenic enzymes, including acetyl-CoA carboxylase, in the mammary gland of rats (Baldwin \& Yang, 1974; Bauman \& Davis, 1974; Dils, 1977; Agius et al. 1979; Flint et al. 1981; McNeillie \& Zammit, I982), rabbits (Gul \& Dils, I969), sheep (Bauman et al. 1974) and mice (Romsos et al. 1978). No change in the proportion of acetyl-CoA carboxylase in the active state was observed in the rat mammary gland (McNeillie \& Zammit, 1982), suggesting that there is a fall in the concentration of key lipogenic enzymes.

In contrast to its effect on the mammary gland, weaning resulted in an increase in the rate of fatty acid synthesis and the activities of various lipogenic enzymes in white adipose tissue from rats (Smith, 1973a; Agius et al. 1979; Flint et al. 198I) and mice (Romsos et al. 1978), brown adipose tissue from rats (Agius \& Williamson, I980a) and liver from rats (Smith, 1973b; Agius et al. 1979; Zammit \& Corstorphine, 1982) but not mice (Romsos et al. 1978). No change in the rate of fatty acid synthesis was observed in sheep adipose tissue $3 \mathrm{~d}$ after removal of the lambs, but changes occur more slowly in sheep than rats and the rate was increased after 1oo d (Vernon et al. 1981).

Fasting. Fasting for $12 \mathrm{~h}$ in the mouse (Romsos et al. 1978), $24 \mathrm{~h}$ in the rat (Williamson, 1980) or $2 \mathrm{~d}$ in the goat (Annison et al. 1968; Chaiyabutr et al. 1980) results in a fall in the rate of milk production and mammary fatty acid synthesis. Studies with the rat have shown that there is an impairment of pyruvate dehydrogenase (Williamson, 1980) and probably acetyl-CoA carboxylase (Munday \& Williamson, 198I). A fall in total activity of acetyl-CoA carboxylase in the mammary gland and also the proportion in the active state occur on fasting in the rat (McNeillie \& Zammit, I982); there is also a decrease in the active proportion of pyruvate dehydrogenase in the active state but no change in total activity (Kankel \& Reinauer, 1976; Baxter \& Coore, I978) which is at least partly due to a fall in pyruvate dehydrogenase phosphatase activity (Baxter \& Coore, 1979). Other factors appear to be involved, since the fall in the rate of fatty acid synthesis is much greater than the fall in acetyl-CoA carboxylase (active state) (McNeillie \& Zammit, 1982) and, when lactating rats were fasted and then refed for $2 \mathrm{~h}$, there was almost complete restoration of the rate of fatty acid synthesis (Williamson, 1980) but no change in the proportion of pyruvate dehydrogenase (Kankel \& Reinauer, 1976) and only partial restoration of acetyl-CoA carboxylase in the active state (Munday \& Williamson, 1982 ).

Fasting diminished the rate of fatty acid synthesis in liver of lactating rats (Robinson et al. 1978) and mice (Romsos et al. 1978) and adipose tissue of lactating mice (Romsos et al. 1978). There was no apparent effect of fasting on fatty acid synthesis in adipose tissue of lactating rats (Robinson et al. 1978), but the rate was already very low and results were expressed/g tissue and so could have been confounded by a loss of lipid, and hence an increase in the number of 
adipocytes/g tissue. Hepatic acetyl-CoA carboxylase and the proportion in the active state fell in fasting lactating rats (Zammit \& Corstorphine, 1982) but the latter change was not observed by Munday \& Williamson ( 1982 ).

\section{Regulation}

How are these changes in the rate of fatty acid synthesis in the various organs produced? Lactation is exceptional in that reciprocal changes occur in different tissues whereas other conditions such as fasting, diabetes and feeding high-fat diets, decrease the rate of fatty acid synthesis at all sites (Williamson, 1980). Thus, novel mechanisms must operate during lactation.

Serum hormone concentration. It is thought that hormones have a major role in regulating fatty acid synthesis. Lactation in most species is characterized by a high serum prolactin concentration (Fig. 4) (Cowie et al. 1980) and a fall in serum prolactin is associated with a fall in the rate of milk production. In ruminants, however, serum prolactin levels decline during lactation and the hormone does not appear to be required for the maintenance of lactation, its role apparently being taken by the structurally similar growth hormone (GH) (Cowie et al. 1980). Serum GH concentration reaches a maximum around peak lactation in ruminants (Fig. 5) (Cowie et al. 1980). In most species serum progesterone, which is elevated during the second half of pregnancy, falls shortly before parturition while serum oestradiol and glucocorticoids peak at parturition (Cowie et al. 1980). In the rabbit there is a preliminary fall in serum progesterone and a rise in serum glucocorticoids at approximately day 20 of pregnancy (Denamur, 1971). In both ruminants and nonruminants, serum glucocorticoid levels are elevated during lactation whereas serum oestradiol levels remain low (Cowie et al. 1980).

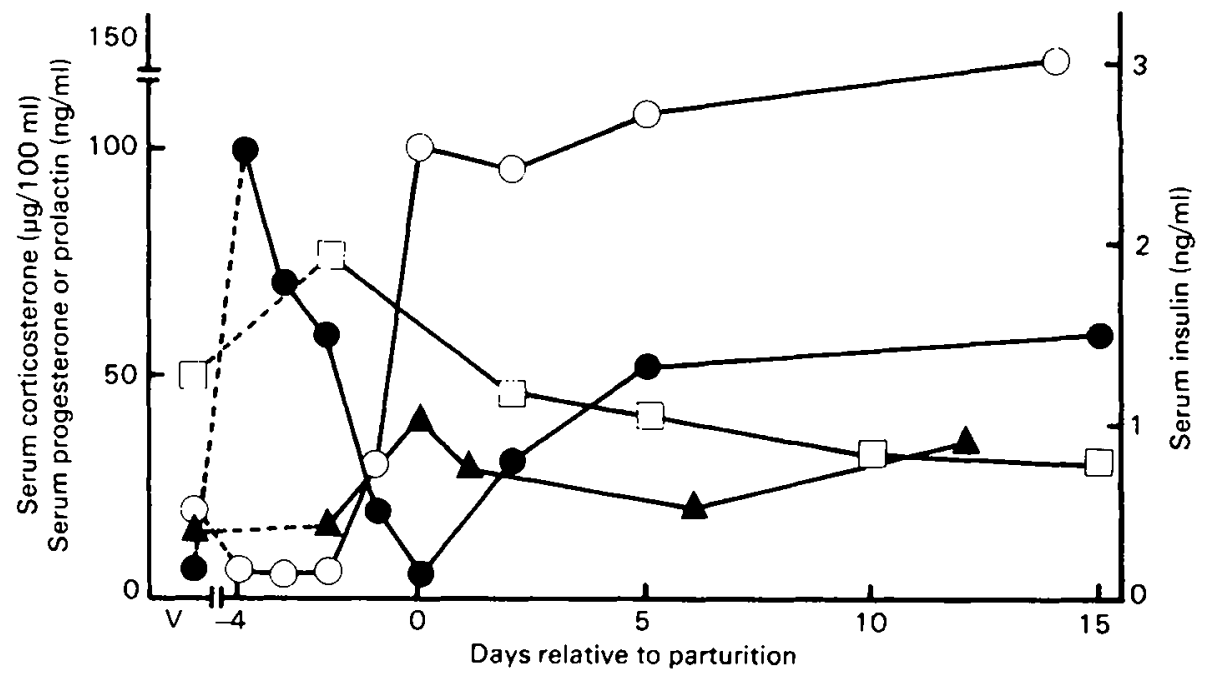

Fig. 4. Serum concentrations of corticosterone $(\Delta)$ (Voogt et al. 1969), progesterone (O) (Morishige et al. 1973), insulin ( $\square$ ) (Flint et al. 1979) and prolactin (O) (Amenomori et al. 1970; Morishige et al. 1973) during pregnancy and lactation in the rat. 


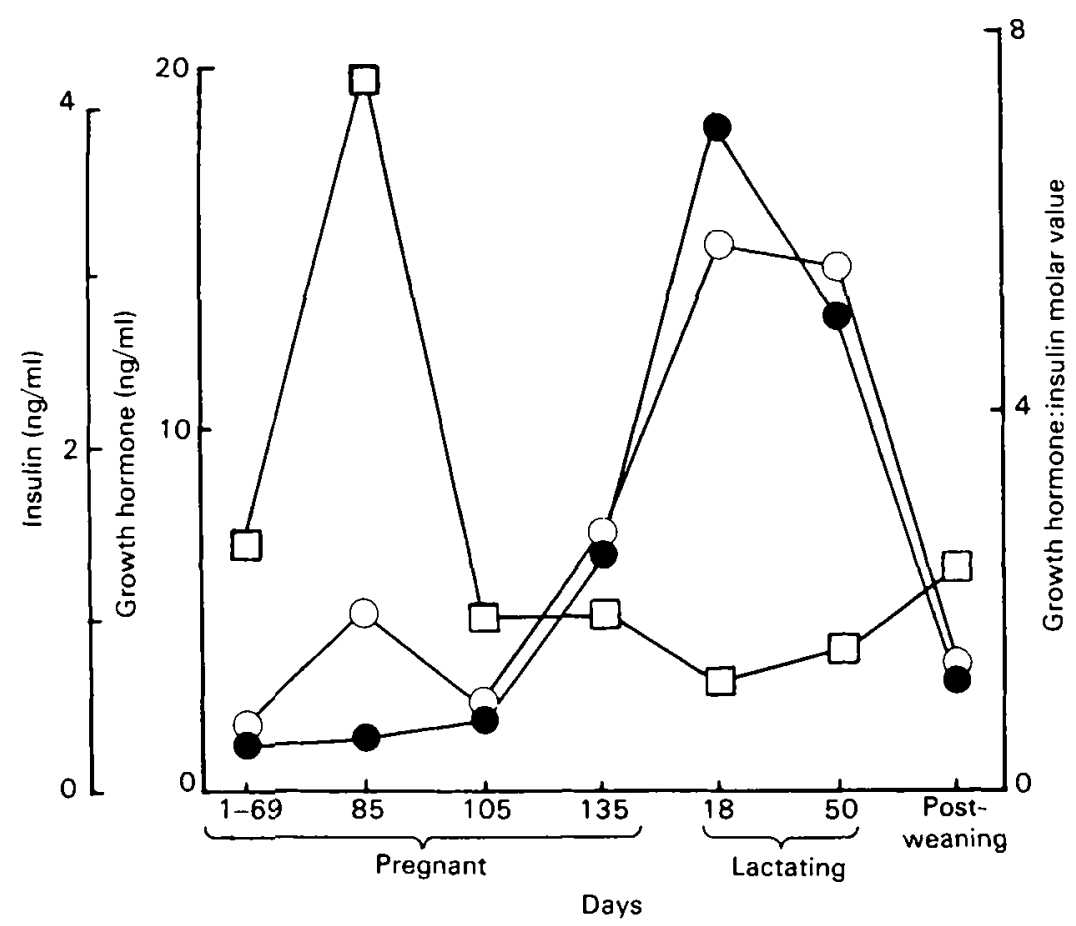

Fig. 5. Serum concentrations of insulin $(\square)$ and growth hormone $(O)$ and growth hormone:insulin molar values $(O)$ in sheep during pregnancy and lactation (from Vernon et al. 198I).

Serum insulin is elevated during pregnancy in rats (Fig. 4) (Knopp et al. 1973), mice (Inagaki \& Kohmoto, 1982) and ruminants (Fig. 5) (Vernon, 1980); in the rat the concentration falls around parturition, reaching the level found in virgin rats by early lactation and even lower levels by mid-lactation (Fig. 4) (Robinson et al. I978). Serum insulin concentration is also depressed during peak lactation in sheep (Fig. 5) and cattle (Cowie et al. I980). Changes in serum glucagon are less well documented, but the evidence to date suggests that there is little change during lactation in the rat (Robinson et al. 1978).

This list of hormonal changes during lactation is not exhaustive, but these are the ones most likely to influence the rate of fatty acid synthesis. Insulin is the major lipogenic hormone in the non-lactating animal and current studies suggest that some of the changes in the rate of fatty acid synthesis with lactation are due to hormones modulating the response of tissues to insulin, as well as to changes in serum insulin concentration itself.

Mammary gland. The development of fatty acid synthesis in the mammary gland around parturition is an integral part of lactogenesis. Studies with a variety of species have shown that the onset of lactogenesis is dependent on the rise in serum prolactin and the fall in serum progesterone; there is also a requirement for glucocorticoids (Baldwin \& Yang, 1974; Kuhn, 1977; Cowie et al. 1980). Maintenance of lactation is generally dependent on prolactin, glucocorticoid and 
insulin (and probably other hormones, e.g. triiodothyronine) although there are some species variations; glucocorticoids do not appear to be essential in the rabbit, prolactin can be replaced by $\mathrm{GH}$ in the goat and insulin is not essential in the ruminant (Tucker, 1974; Cowie et al. 1980).

The hormonal requirements of mammary fatty acid synthesis appear to be the same as those for lactogenesis and lactation in general. Endocrine ablation and replacement therapy have shown a requirement for prolactin and glucocorticoids in the development of fatty acid synthesis in the rat (Abraham et al. 1960) but decreases in serum progesterone, removal of colostrum from the gland (Martyn \& Hansen, 1980) and acetyl-CoA carboxylase activity (Martyn \& Hansen, I98I) in vivo are also required in the rat. Most studies have involved the tissue culture of explants of mammary gland from pregnant animals (Dils, 1977; Dils et al. 1977; Mayer, 1978). Such studies have shown that the combination of insulin, glucocorticoid and prolactin are required for the development of mammary fatty acid synthesis in rats, mice, rabbits (Dils, 1977; Dils et al. 1977; Mayer, 1978), goats (Skarda et al. 1978, 1982), cows (Collier et al. 1977) and even water buffalo (Bhatia et al. 1979).

Adrenalectomy, but not ovariectomy, results in a fall in mammary fatty acid synthesis in the lactating rat (Baldwin \& Yang, 1974; Cowie et al. 1980). Administration of bromocriptine has similar effects and markedly reduces the serum prolactin concentration (Williamson, 1980) and the activities of pyruvate

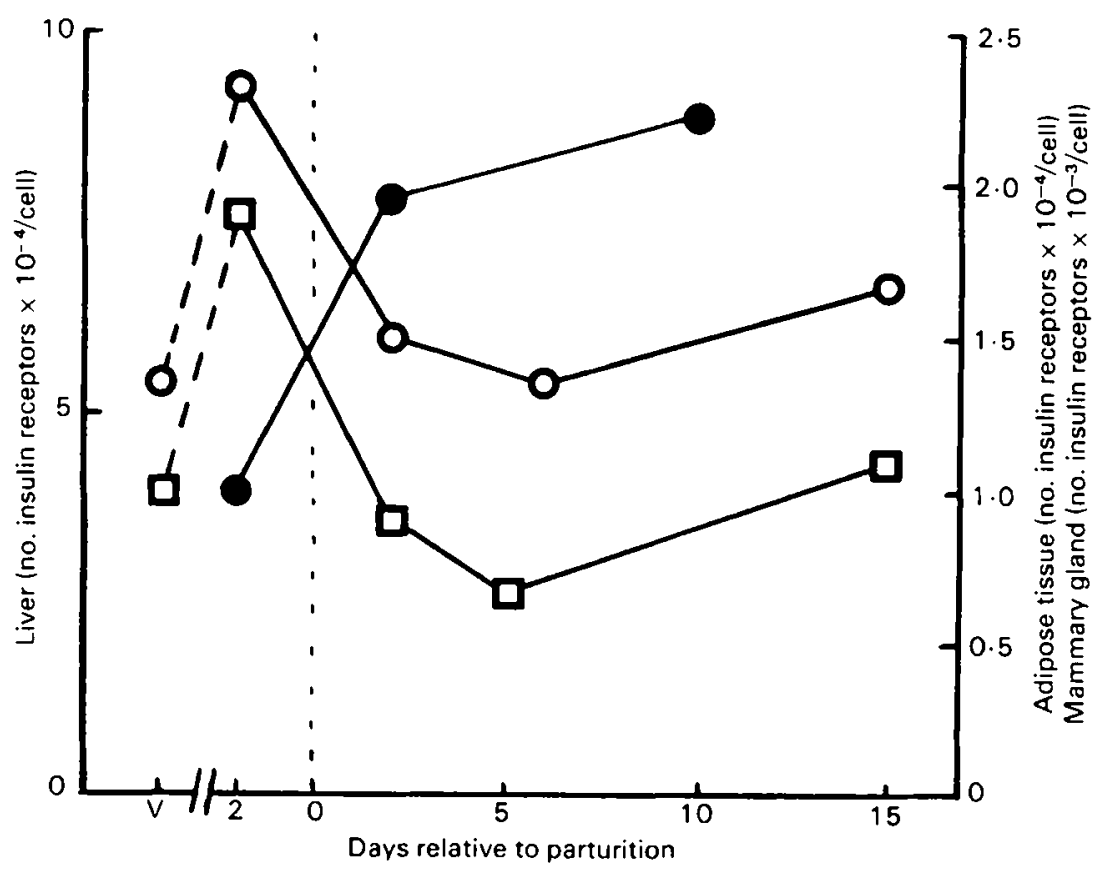

Fig. 6. Number of insulin receptors with a high affinity for insulin $\left(K_{\mathrm{d}} \approx \mathrm{I} \mathrm{nM}\right)$ of rat adipocytes ( $\square$ ) (Flint et al. 1979), hepatocytes (O) (Flint, 1980) and mammary acini cells (O) (Flint, I $982 a)$ during pregnancy and lactation. $\mathrm{V}$, virgin. 
dehydrogenase (Field \& Coore, 1976) and acetyl-CoA carboxylase (McNeillie \& Zammit, 1982; Munday \& Williamson, 1982).

Insulin deficiency for several days leads to a loss of mammary alveolar cells in the rat (Baldwin \& Yang, 1974; Cowie et al. 1980). Short-term insulin deficiency $(2-3 \mathrm{~h})$ leads to a fall in the rate of mammary fatty acid synthesis (Williamson, 1980) and a fall in the proportions of acetyl-CoA carboxylase (McNeillie \& Zammit, 1982; Munday \& Williamson, 1982) and pyruvate dehydrogenase (Field \& Coore, 1976) in the active form; total activities of the enzymes were unchanged. Administration of insulin to lactating rats had no effect on the rate of fatty acid synthesis (Agius \& Williamson, 1980b) or the yield of milk fat (Raskin et al. 1973).

The action of peptide hormones on a tissue begins with their binding to receptors on the cell surface. The number of insulin receptors on mammary epithelial cells from rats (Fig. 6) and mice (O'Keefe \& Cuatrecasas, 1974; Inagaki \& Kohmoto, 1982) increase around parturition and this appears to be linked to the fall in serum progesterone (Flint, $1982 a$ ). A decrease in serum prolactin during lactation results in a fall in the number of insulin receptors (Flint, $1982 b$ ). Thus changes in the rate of fatty acid synthesis in the mammary gland in response to various treatments appear to be paralleled by changes in the number of insulin receptors of the tissue.

The role of insulin in the regulation of fatty acid synthesis in the ruminant mammary gland is uncertain. No effects of insulin were observed on the rate of fatty acid synthesis in slices of mammary tissue from lactating sheep (Balmain \& Folley, 195 I Balmain et al. 1954) or cows (Bauman et al. 1973) but insulin treatment can increase the yield of milk fat in cattle (Cowie et al. 1980).

White adipose tissue. Insulin is the major hormone promoting fatty acid synthesis in adipose tissue and exerts its effect by both short-term (substrate uptake, enzyme activation) and long-term (enzyme concentration) mechanisms. A decreased serum insulin concentration is found at peak lactation in both rats and ruminants and is likely to reduce fatty acid synthesis in adipose tissue. However, it is pertinent to note that fatty acid synthesis in rat adipose tissue is markedly reduced during early lactation despite serum insulin concentrations similar to those found in virgin rats (Flint et al. 1979), suggesting that the effects of insulin on adipose tissue are muted during lactation. The serum concentration of glucagon, which inhibits the activity of acetyl-CoA carboxylase in rat adipose tissue (V. A. Zammit, personal communication), does not change during lactation (see above) so this would not appear to be the factor responsible for the diminished response of the tissue to insulin.

As already mentioned, the initial step in the interaction of insulin with a target cell is the binding of the hormone to its receptor on the cell surface. During pregnancy, the number of insulin receptors of rat adipocytes is increased; around parturition the number returns to levels found on cells from virgin rats but there is no further fall in their number during lactation (Fig. 6). Further studies have shown that the fall in both the number of insulin receptors and the rate of fatty acid synthesis of adipocytes around parturition in the rat are linked to the fall in 
serum progesterone (Flint et al. 1980) (cf. the mammary gland, above). Lowering of serum prolactin during lactation by administration of bromocriptine or by weaning resulted in an increase in both the number of insulin receptors and the rate of fatty acid synthesis in rat adipocytes: the effects of bromocriptine could be prevented by concurrent administration of prolactin, but administration of this hormone could retard the effects of weaning for $24 \mathrm{~h}$ only (Flint et al. $\mathrm{I} 98 \mathrm{r}$; see also Agius et al. 1979). Weaning also lowered the number of insulin receptors of rat mammary tissue; this could not be prevented by administration of prolactin (Flint, 1982b). Thus, as summarized in Table 2, changes in the rate of fatty acid synthesis in rat adipose tissue and mammary gland during lactation are paralleled by changes in the number of insulin receptors of the two tissues; both progesterone and prolactin have reciprocal effects on these properties of the two tissues. Progesterone probably acts directly on both tissues as progesterone receptors have been demonstrated in rat adipose tissue (Gray \& Wade, 1979) and mammary gland, although in the case of the latter it may be binding to a glucocorticoid receptor (Cowie et al. 1980). Prolactin receptors have also been demonstrated in mammary tissue (Cowie et al. 1980 ) but we have been unable to demonstrate their presence in rat adipose tissue: this observation, plus the fact that prolactin could not prevent the effects of weaning on rat adipose tissue metabolism for more than $24 \mathrm{~h}$, suggests that prolactin may not act directly on adipose tissue in the rat.

Although changes in the rate of fatty acid synthesis of rat adipocytes during pregnancy and lactation appear to be linked to changes in the numbers of insulin receptors, additional factors are required to account for the low rate of fatty acid synthesis during lactation as the numbers of insulin receptors are similar to those found in adipocytes of virgin rats. The binding of insulin to its receptor leads to the internalization of the hormone-receptor complex by endocytosis (Jacobs \& Cuatrecasas, $198 \mathrm{r}$; Olefsky et al. 1982). High serum insulin concentrations in vivo or exposure of cells to insulin for several hours in vitro (Jacobs \& Cuatrecasas,

Table 2. Summary of changes in the rate of fatty acid synthesis and the number of insulin receptors in mammary gland and adipose tissue from rats during pregnancy and lactation

(See above for references)

\section{Late pregnancy}

Late pregnancy, effect of lowering serum progesterone

Mid-lactation

Mid-lactation, effect of lowering serum prolactin

$\begin{array}{llll}\begin{array}{l}\text { Fatty acid } \\ \text { synthesis } \\ \text { Low }\end{array} & \begin{array}{l}\text { Insulin } \\ \text { receptors } \\ \text { Low }\end{array} & \overbrace{\begin{array}{l}\text { Fatty acid } \\ \text { synthesis } \\ \text { Normal }\end{array}}^{\text {Mammary }} & \begin{array}{l}\text { Insulin } \\ \text { receptors } \\ \text { High* }\end{array} \\ \begin{array}{llll}\text { Increased } \\ \text { High }\end{array} & \begin{array}{l}\text { Increased } \\ \text { High }\end{array} & \begin{array}{l}\text { Decreased } \\ \text { Low }\end{array} & \begin{array}{l}\text { Decreased } \\ \text { Normal }\end{array} \\ \text { Decreased } & \text { Decreased } & \text { Increased } & \text { Increased }\end{array}$

- Relative to value found for virgin rats. 
Table 3. Effects of culture in the presence of insulin on the subsequent ability of isolated adipocytes to bind ${ }^{125}$ I-labelled insulin $\uparrow$

(Mean values with their standard errors for at least five separate observations using cells pooled from two animals for each observation)

\begin{tabular}{|c|c|c|c|c|c|c|c|c|}
\hline & & & ${ }^{125}$ I-labe & insulin & ound ( $p$ & $o^{3}$ cells & & \\
\hline & & & & & & & & \\
\hline & Contr & $24 \mathrm{~h})$ & Insulin & $-24 h)$ & Cont & $4^{8 h)}$ & Insulin & $\left.-4^{8 h}\right)$ \\
\hline & Mean & SEM & Mean & SEM & Mean & SEM & Mean & SEM \\
\hline Virgin & 12.9 & $2 \cdot 2$ & $9.0^{\circ}$ & I. 4 & 10.4 & $I \cdot 6$ & $6 \cdot 1^{\bullet}$ & 0.8 \\
\hline Pregnant & 20.9 & $2 \cdot I$ & $22 \cdot 7$ & $2 \cdot 9$ & 15.2 & $1 \cdot 7$ & $10.4^{\circ 0}$ & $1 \cdot 9$ \\
\hline Lactating & I I $\cdot 5$ & I $\cdot 7$ & 12.0 & $2 \cdot 4$ & $7 \cdot 1$ & 0.9 & 6.6 & $I \cdot I$ \\
\hline
\end{tabular}

† Adipocytes were cultured at $37^{\circ}$ in medium 199 . All values were corrected for non-specific binding, which approximated to $5-25 \%$ of the total binding.

$\bullet P<0.05, \cdots P<0.01$, compared with the respective control (Student's paired $t$ test).

I981; Olefsky et al. 1982) can lead to a loss of insulin receptors from the cell surface; this has been called 'down' regulation (Gavin et al. 1974). Rat adipocytes from virgin rats can be maintained in cell culture for up to $4^{8} \mathrm{~h}$ without loss of insulin receptors (Walker \& Flint, 1983 ). Addition of insulin to the culture medium, however, leads to a time and concentration dependent loss of insulin receptors (Table 3). Similar experiments with adipocytes from pregnant and lactating rats showed that the 'down' regulation of the insulin receptor was absent, although it reappeared after $24 \mathrm{~h}$ of cell culture in the case of cells from the pregnant rats (Table 3). The importance of the internalization process in the mechanism of insulin action is by no means certain, and some rapid effects of insulin (e.g. on glucose uptake) are not thought to involve internalization (Hammons \& Jarett, 1979; Marshall \& Olefsky, 1980). On the other hand, internalization may be a key process in the long-term effects of insulin in which a signal needs to be transmitted to the nucleus for example. These observations suggest that the muted response of rat adipocytes to insulin during lactation may be due to an impairment in the processing of the insulin-receptor complex.

Our knowledge of the mechanisms which regulate the metabolism of ruminant adipose tissue during lactation is much less than for the rat and there appear to be important differences. Although changes in the numbers of insulin receptors occur during pregnancy, no changes were observed around parturition or during lactation (Vernon et al. $198 \mathrm{I}$ ). GH rather than prolactin is the essential hormone for the maintenance of established lactation in the ruminant and it is thought to have a key role in promoting the preferential utilization of nutrients by the mammary gland in lactating ruminants (Cowie et al. 1980). The serum GH:insulin value is very high during lactation in sheep (Fig. 6) and cattle (Cowie et al. 1980). Also, unlike prolactin, GH probably acts on adipose tissue directly since GH 
receptors have been demonstrated on fat cells from rats (Fagin et al. 1980; Herington, 1982) and, although receptors have not been shown in ruminant fat cells, an insulin-antagonistic effect of physiological concentrations of $\mathrm{GH}$ has been shown with sheep adipose tissue in vitro (Vernon, 1982). How GH exerts its insulin-antagonistic effect is not known.

Liver. The mechanisms responsible for the changes in hepatic fatty acid synthesis during lactation are not clear. Insulin promotes fatty acid synthesis in the liver so the fall in serum insulin during lactation (Fig. 4) would be expected to lead to a decrease in the rate of hepatic fatty acid synthesis. The number of insulin receptors in rat liver is increased during pregnancy but returns to the levels of virgin rats by early lactation (Flint, $\mathrm{I} 980$ ) and so changes in binding capacity do not provide an answer. Prolactin can act directly on the liver as receptors for prolactin have been demonstrated (Cowie et al. 1980) but weaning or bromocriptine administration results in an increase in the rate of hepatic fatty acid synthesis which is blocked by administration of prolactin (Agius et al. 1979).

Nutrient supply to the liver is greatly increased during lactation because of the increased food intake (Hanwell \& Peaker, 1977; Williamson, 1980) and there is also an increase in hepatic blood flow (Hanwell \& Peaker, 1977). The liver receives most of its blood from the hepatic portal vein which also drains the pancreas, so it is possible that the portal vein insulin concentration is elevated during lactation (an increased hepatic extraction of insulin would account for the lower peripheral serum insulin concentration): this possibility has not been explored as yet in the rat but results for the cow (Lomax et al. 1979) tend to mitigate against it.

\section{Summary and conclusions}

Lactation results not only in an increased rate of fatty acid synthesis in the mammary gland but also in a decreased rate of fatty acid synthesis in adipose tissue and, in the rat at least, an increased rate of hepatic fatty acid synthesis. Progesterone (during pregnancy), prolactin and (in ruminants) GH are implicated in the regulation of the reciprocal changes in fatty acid synthesis in mammary gland and adipose tissue. Progesterone and prolactin, at least, appear to influence the rate of fatty acid synthesis by modulating the insulin-binding capacities of the tissues, but it is clear that steps in the mechanism of action of insulin subsequent to its binding to the receptor are also changed in adipose tissue during lactation.

\section{REFERENCES}

Abraham, S., Cady, P. \& Chaikoff, I. L. (I960). Endocrinology 66, 280.

Agius, L., Blackshear, P. J. \& Williamson, D. H. (198I). Biochem. f. 196, 637.

Agius, L., Robinson, A. M., Girard, J. R. \& Williamson, D. H. (1979). Biochem. f. 180, 689.

Agius, L. \& Williamson, D. H. (1980a). Biochem. F. 190, 477 .

Agius, L. \& Williamson, D. H. (1980b). Biochem. $\mathcal{Y}$. 192, 36r.

Amenomori, Y., Chen, C. L. \& Meites, J. (1970). Endocrinology 86, 506.

Annison, E. F., Linzell, J. L. \& West, C. E. (1968). F. Physiol., Lond. 197, 445. 
Baldner, G. L., Torok, E. D., Johnson, D. C. \& Beitz, D. C. (1982). Fedn Proc., Fedn Am. Socs exp. Biol. 4r, 343 .

Baldwin, R. L. \& Yang, Y. T. (1974). In Lactation: a Comprehensive Treatise, vol. I, p. 349 [B. L. Larson and V. R. Smith, editors]. London and New York: Academic Press.

Balmain, J. H. \& Folley, S. J. (1951). Biochem. f. 49, 663.

Balmain, J. H., Folley, S. J. \& Glascock, R. F. (1954). Biochem. f. 56, 234.

Bartley, J. C. \& Abraham, S. (1976). F. Lipid Res. 17, 467.

Bartley, J. C., Emerman, J. T. \& Bissell, M. J. (I98I). Am. F. Physiol. 241, C204.

Bauman, D. E. \& Currie, W. B. (1980). F. Dairy Sci. 63, 1514.

Bauman, D. E. \& Davis, C. L. (1974). In Lactation: a Comprehensive Treatise, vol. 2, p. 31 [B. L. Larson and V. R. Smith, editors]. London and New York: Academic Press.

Bauman, D. E. \& Davis, C. L. (1975). In Digestion and Metabolism in the Ruminant, p. 496 [I. W. McDonald and A. C. I. Warner, editors]. Armidale: University of New England Publishing Unit.

Bauman, D. E., Ingle, D. L., Mellenberger, R. W. \& Davis, C. L. (1973). F. Dairy Sci. 56, I520.

Bauman, D. E., Mellenberger, R. W. \& Ingle, D. L. (1974). F. Dairy Sci. 57, 719.

Baxter, M. A. \& Coore, H. G. (1978). Biochem. F. 174, 553.

Baxter, M. A. \& Coore, H. G. (1979). Biochem. biophys. Res. Commun. 87, 433.

Bell, A. W. (1979). Prog. Lipid Res. 18, 17.

Bhatia, I. S., Saxena, A. K. \& Ahuja, S. P. (1979). Zbl. Vet. Med. 26, 309.

Chaiyabutr, N., Faulkner, A. \& Peaker, M. (1980). Biochem. F. 186, 301.

Chilliard, Y., Durand, G., Sauvant, D. \& Morand-Fehr, P. (1978). C. R. Acad. Sci., Paris 287, 1131 .

Collier, R. J., Bauman, D. E. \& Hays, R. L. (1977). Endocrinology 100, 1192.

Coore, H. G. \& Field, B. (1975). Biochem. f. 142,87.

Cowie, A. T., Forsyth, I. A. \& Hart, I. C. (1980). Hormonal Control of Lactation. Berlin: Springer-Verlag.

Crabtree, B., Taylor, D. J., Coombs, J. E., Smith, R. A., Templer, S. P. \& Smith, G. H. (198ı). Biochem. F. 196, 747.

Denamur, R. (197I). F. Dairy Res. 38, 237.

Dils, R. R. (1977). In Lipid Metabolism in Mammals, vol. 2, p. I 3 r [F. Synder, editor]. New York: Plenum Press.

Dils, R. R., Clark, S. \& Knudsen, J. (1977). In Comparative Aspects of Lactation, p. 43 [M. Peaker, editor]. London and New York: Academic Press.

Dils, R. R. \& Knudsen, J. (1980). Biochem. Soc. Trans. 8, 292.

Fagin, K. D., Lackey, S. L., Reagan, C. R. \& Di Girolamo, M. (1980). Endocrinology 107, 608.

Farid, M., Baldwin, R. L., Yang, Y. T., Osborne, E. \& Grichting, G. (1978). J. Nutr. 108, 514.

Field, B. \& Coore, H. G. (1976). Biochem. F. 156, 333 .

Flint, D. J. (1980). Biochim. biophys. Acta 628, 322.

Flint, D. J. (1982a). Mol. Cell Endocr. 26, 281.

Flint, D. J. (1982b). F. Endocr. 93, 279.

Flint, D. J., Clegg, R. A. \& Vernon, R. G. (1980). Mol. Cell Endocr. 20, 101.

Flint, D. J., Clegg, R. A. \& Vernon, R. G. (1981). Mol. Cell Endocr. 22, 265.

Flint, D. J., Sinnett-Smith, P. A., Clegg, R. A. \& Vernon, R. G. (1979). Biochem. F. 182, 421.

Gavin, J. R., Roth, J., Neville, D., DeMeyts, P. D. \& Buell, D. N. (1974). Proc. natn. Acad. Sci., USA 71, 84 .

Gray, J. M. \& Wade, G. N. (1979). Endocrinology 104, ז 377 .

Grichting, G., Baldwin, R. L. \& Smith, N. E. (1977). F. Dairy Sci. 60, Suppl. 1, 120.

Grichting, G., Smith, N. E. \& Baldwin, R. L. (1977). Fedn Proc. Fedn Am. Socs exp. Biol. 36, 1141 .

Gul, B. \& Dils, R. (1969). Biochem. F. 112, 293.

Hammons, G. T. \& Jarett, L. (1979). Diabetes 28, 389.

Hanwell, A. \& Peaker, M. (1977). In Comparative Aspects of Lactation, Symp. Zool. Soc. London, no. 4I, p. 297 [M. Peaker, editor]. London and New York: Academic Press.

Hardie, D. G. \& Guy, P. S. (1980). Eur. F. Biochem. 110, 167.

Herington, A. C. (1982). 7. Receptor Res. 2, 299.

Hollands, M. A. \& Cawthorne, M. A. (1981). Biochem. F. 196, 645 . 
Inagaki, Y. \& Kohmoto, K. (1982). Endocrinology $110,176$.

Jacobs, S. \& Cuatrecasas, P. (1981). Endocr. Revs 2, 251.

Jones, C. S. \& Parker, D. S. (1978). Biochem. F. 174, 291.

Kankel, K. F. \& Reinauer, H. (1976). Diabetologia 12, 149.

Katz, J., Wals, P. A. \& Van de Velde, R. L. (1974). F. biol. Chem. 249, 7348.

Kensinger, R. S., Collier, R. J., Bazer, F. W., Ducsay, C. A. \& Becker, H. N. (1982). J. Anim. Sci. 54, I 297.

Knopp, R. H., Saudek, C. D., Arky, R. A. \& O'Sullivan, J. B. (1973). Endocrinology 92, 984.

Kuhn, N. J. (1977). In Comparative Aspects of Lactation, p. I65 [M. Peaker, editor]. London and New York: Academic Press.

Linzell, J. L. (1974). In Lactation: a Comprehensive Treatise, vol. I, p. 143 [B. L. Larson and V. R. Smith, editors]. London and New York: Academic Press.

Lomax, M. A., Baird, G. D., Mallinson, C. B. \& Symonds, M. W. (1979). Biochem. F. 180, 281.

Mackall, J. C. \& Lane, D. M. (1977). Biochem. F. 162, 635.

McNeillie, E. M., Clegg, R. A. \& Zammit, V. A. (1981). Biochem. f. 200, 639.

McNeillie, E. M. \& Zammit, V. A. (1982). Biochem. F. 204, 273.

Marshall, S. \& Olefsky, J. M. (1980). Endocrinology 107, 1937.

Martyn, P. \& Hansen, I. A. (1980). Biochem. f. 190, 171 .

Martyn, P. \& Hansen, I. A. (1981). Biochem. F. 198, 187.

Mayer, R. J. (1978). Vitams \& Horm. 36, I01.

Mellenberger, R. W. \& Bauman, D. E. (1974). Biochem. f. 138, 373.

Mellenberger, R. W., Bauman, D. E. \& Nelson, D. R. (1973). Biochem. $\mathcal{F} . \times 36,741$.

Moore, J. H. \& Christie, W. W. (1979). Prog. Lipid Res. 17, 347.

Morishige, W. K., Pepe, G. J. \& Rothchild, I. (1973). Endocrinology 92, 1527.

Munday, M. R. \& Williamson, D. H. (1981). Biochem. F. 196, 831 .

Munday, M. R. \& Williamson, D. H. (1982). FEBS Lett. 138, 285.

O'Keefe, E. \& Cuatrecasas, P. (1974). Biochim. biophys. Acta 343, 64.

Olefsky, J. M., Marshall, S., Berhany, P., Saekow, M., Heidenreich, K. \& Green, A. (1982). Metabolism 31, 670.

Patton, S. \& Jensen, R. G. (1975). In Progress in Chemistry and Fats and Other Lipids, vol. 14, p. 163 [R. J. Holman, editor]. Oxford: Pergamon Press.

Pearce, J. (1983). Proc. Nutr. Soc. 42, 263.

Pike, B. V. \& Roberts, C. J. (1981). Res. vet. Sci. 30, 390.

Raskin, R. L., Raskin, M. \& Baldwin, R. L. (1973). F. Dairy Sci. 56, 1033.

Read, G., Crabtree, B. \& Smith, G. H. (1977). Biochem. F. 164, 349.

Robinson, A. M., Girard, J. R. \& Williamson, D. H. (1978). Biochem. f. 176, 343.

Romsos, D. R., Muiruri, K. L., Lin, P. Y. \& Leveille, G. A. (1978). Proc. Soc. exp. Biol. Med. I59, 308.

Rothwell, N. J. \& Stock, M. J. (1979). Nature, Lond. 281, 31.

Sinnett-Smith, P. A., Vernon, R. G. \& Mayer, R. J. (1980). Biochem. f. 186, 933.

Sinnett-Smith, P. A., Vernon, R. G. \& Mayer, R. J. (1982). Biochim. biophys. Acta 714, $5^{8}$.

Skarda, J., Bilek, J. \& Urbanova, E. (1978). Physiol. Biochem. 27, 53.

Skarda, J., Urbanova, E., Houdebine, L-M., Delouis, C. \& Bilek, J. (Ig82). Reprod. Nutr. Develop. 22, 379.

Smith, R. W. (1973a). 7. Dairy Res. 40, 353.

Smith, R. W. (1973b). F. Dairy Res. 40, 339 .

Smith, S. (1980). F. Dairy Sci. 63, 337.

Smith, S. \& Abraham, S. (1975). Adv. Lipid Res. 25, 195.

Spray, C. M. (1950). Br. J. Nutr. 4, 354.

Strong, C. R. \& Dils, R. (1972). Biochem. $\mathcal{F}$. 128, 1303.

Trayhurn, P., Douglas, J. B. \& McGuckin, M. M. (1982). Nature, Lond. 298, 59.

Tucker, H. A. (1974). In Lactation, vol. I, p. 277 [B. L. Larson and V. R. Smith, editors]. London and New York: Academic Press.

Vernon, R. G. (1980). Prog. Lipid Res. 19, 23.

Vernon, R. G. (1982). Int. F. Biochem. 14, 255.

Vernon, R. G., Clegg, R. A. \& Flint, D. J. (1981). Biochem. J. 200, 307.

Voogt, J. L., Sar, M. \& Meites, J. (1969). Am. Y. Physiol. $216,655$. 
Walker, A. P. \& Flint, D. J. (1983). Biochem. f. (In the Press.)

Williamson, D. H. (1980). FEBS Lett. 117 , Suppl., K93.

Yang, Y. T. \& Baldwin, R. L. (1975). f. Dairy Sci. 58, 337.

Zammit, V. A. \& Corstorphine, C. G. (1982). Biochem. F. 204, 757. 